\title{
EL CINE DOCUMENTAL Y LA ANTROPOLOGÍA VISUAL EN MÉXICO
}

\author{
Entrevista - Antonio Zirión Pérez
}

Por Bianca Pires ${ }^{1}$ y Claudia Lora ${ }^{2}$

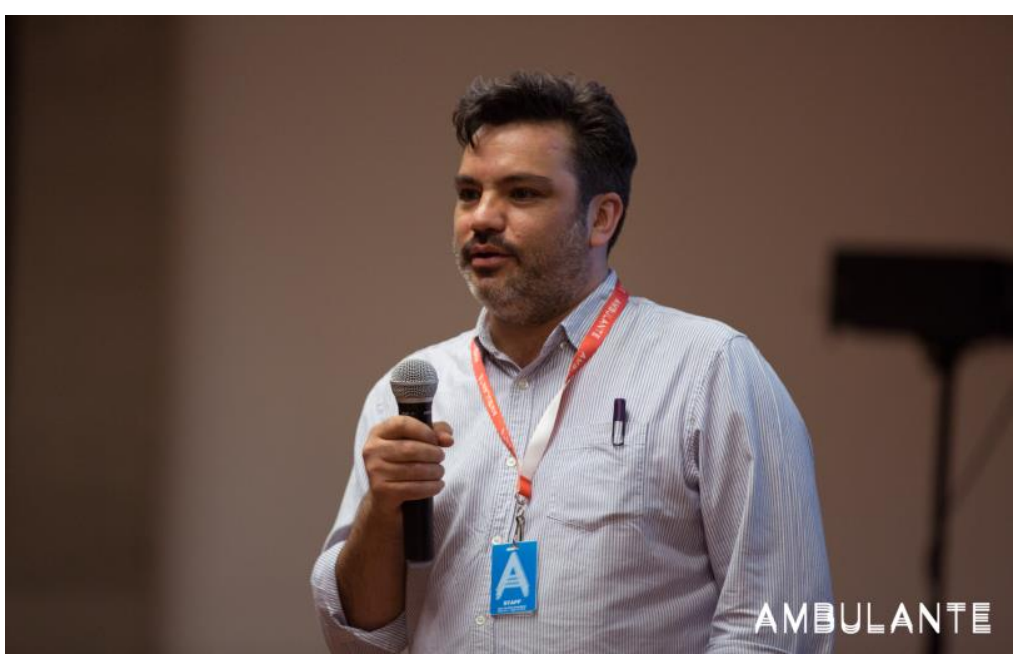

António Zirión. (Cortesía del Festival de Cine Documental Itinerante Ambulante).

Antonio Zirión Pérez es una referencia en la Antropología Audiovisual mexicana. Profesor de la Universidad Autónoma Metropolitana, unidad Iztapalapa (UAM-I) en la Ciudad de México, vinculado al Laboratorio de Antropología Visual, espacio pionero en la formación de estudiantes interesados en esta área. Como estudiante de etnología de la Escuela Nacional de Antropología y Historia (ENAH), desarrolló investigaciones participativas usando la fotografía como herramienta de trabajo con jóvenes callejeros del barrio La Soledad, zona marginal del centro de la Ciudad de México. Como despliegue de su monografía de licenciatura, desarrolló el cortometraje "Chido mi Banda, Chido mi Barrio" (2000), junto con sus compañeros Adrián Arce y Diego Rivera; trio que posteriormente se convirtió en el colectivo Homovidens. La estrategia de investigación-producción promovida por el colectivo tenía la finalidad de involucrar a estos jóvenes en las grabaciones del documental, herramienta usada por el llamado documental participativo. El proyecto ganó nuevas proporciones

\footnotetext{
${ }^{1}$ Bianca Salles Pires. Doutoranda do Programa de Pós-graduação em Sociologia e Antropología. Universidade Federal do Rio de Janeiro.

${ }^{2}$ Rosa Claudia Lora Krstulovic. Doutora em memoria social pela UNIRIO. Atualmente doutoranda em cinema documentário na UNAM, México.
} 
a partir de financiamientos privados, con los que ofrecieron cursos de video y fotografía a jóvenes de otros barrios y comunidades de la Ciudad de México. Todo el proceso de enseñanza-aprendizaje fue registrado y los diferentes materiales generaron el largometraje "Voces de la Guerrero" (2004), ganador del premio José Rovirosa al mejor documental del año, ofrecido por la Universidad Nacional Autónoma de México (UNAM). Tras la buena recepción de la película, el autor sale del país para estudiar la maestría en Antropología Visual en el Granada Centre for Visual Antrhopology, en la Universidad de Manchester, en Inglaterra. Cuando regresa a México, cursa su doctorado en Ciencias Antropológicas en la UAM-I bajo la dirección de Néstor García Canclini.

En el año 2013, el colectivo Homovidens realiza un nuevo proyecto con jóvenes, esta vez con presos de la Comunidad de Tratamiento Especial para Adolescentes de San Fernando, localizado en la zona sur de la Ciudad de México. El resultado del proceso colaborativo fue el documental "Fuera de Foco" (2013), ganador del Premio a Mejor Documental en el 5to Festival do Filme Etnográfico de Recife, Brasil. En el año de 2011. Tras la jubilación del profesor estadounidense Scott Robinson, fundador del Laboratorio de Antropología Visual en la UAM-I, Antonio Zirión asume definitivamente la responsabilidad de dar continuidad a la enseñanza de la antropología visual en la UAM-I. Desde entonces, el Laboratorio ofrece talleres y se imparten diversas disciplinas teóricas y prácticas en la licenciatura y posgrado en antropología, en las cuales los estudiantes nacionales y extranjeros tienen la oportunidad de desarrollar el uso de lenguajes audiovisuales como método de investigación social. Parte de la rica producción de los estudiantes se encuentra disponible en la plataforma Captura de Significados (http://capturadesignificado.org/).

Paralelamente a su formación académica y su labor docente en la UAM-I, Antonio Zirión participa como curador y programador de festivales de cine documental, entre ellos DocsDF, DocsMX (https://docsmx.org/) y actualmente en la Gira de Documentales Ambulante (www.ambulante.com.mx). En los últimos años, Antonio ha escrito artículos donde describe la importancia de los festivales de documental para la formación de públicos y para la circulación de obras que difícilmente encuentran ventanas de exhibición. Frente a las múltiples relaciones que este antropólogo establece con la enseñanza y la investigación antropológica, en 
paralelo con su trabajo de producción y curaduría de festivales audiovisuales, proponemos esta entrevista para el presente Dossiê. Durante la conversación, realizada en la tarde del día 14 de mayo de 2019 en la UAM-I, el profesor nos compartió algunas de sus reflexiones sobre el actual escenario del cine documental mexicano.

\section{¿Nos puedes contar un poco sobre tu trayectoria como antropó- logo, tu formación y tus proyectos actuales?}

Estudié la carrera de etnología en la ENAH a la par que estudiaba filosofía en la UNAM. Llevaba las dos carreras hasta que estalló una huelga de 9 meses en la UNAM, que de manera natural me llevo a enfocarme más en la carrera de etnología, para la que ya estaba empezando a hacer mi investigación de tesis. Acabé abandonando la carrera en filosofía, pero todo lo que estudié me ayudó mucho y creo que lo sigo aprovechando en cada trabajo que hago, esa mirada crítica que te da la filosofía, se quedaron arraigadas en mi formación. Hice mi investigación de tesis de licenciatura sobre un barrio que se llama el barrio de La Soledad, con muchos problemas urbanos como niños de la calle, prostitución, drogadicción y muchos cultos y brujería urbana. Ahí empecé a utilizar de manera incipiente las cámaras de fotografía primero, y después de video, como un instrumento de investigación; así fue como descubrí que existía algo que se llamaba antropología visual. pero en realidad yo lo había empezado a hacer de manera intuitiva. Cuando terminé esa experiencia seguí haciendo documentales con ayuda de algunos amigos que habían estudiado cine, tuve la oportunidad de irme a la Universidad de Manchester al Granada Centre a hacer una maestría en antropología visual y después de eso regresé a completar mi formación como antropólogo en el doctorado en ciencias antropológicas en la UAM-I, hice una tesis sobre albañiles, trabajadores de la construcción, también empleando ciertas metodologías audiovisuales y tratando de entender el desarrollo urbano de la Ciudad de México desde su perspectiva. Tuve la suerte de que cuando obtuve el grado, me invitaron a trabajar como profesor visitante en el mismo Departamento, y a los tres años se jubiló el profesor Scott Robinson que había fundado el Laboratorio de antropología visual y entonces se abrió una plaza justo con el perfil de antropología visual. Tuve la suerte de ganar el concurso

CSOnline - Revista Eletrônica de Ciências Sociais, Juiz de Fora, n. 29 (2019) 
de oposición y desde 2011 trabajo aquí en el Departamento en antropología y muy de cerca del Laboratorio de antropología visual, que había sido fundado alrededor del año 2000. Poco a poco, no fue de un momento a otro, sino que costó mucho tiempo ir montando un centro de producción de video, que en aquel momento era video analógico y bueno se consiguió financiamiento para comprar equipo y se comenzó a dar clases de antropología visual y a capacitar a algunos alumnos en las técnicas básicas de producción, de fotografía y cine documental. Desde entonces se constituyó este laboratorio que era en aquel momento un espacio único en México para hacer antropología visual, un espacio pionero y visionario que con el tiempo ha demostrado su pertinencia y su urgencia, porque son pocas las instituciones que tienen una línea de investigación o espacios formativos y de producción en antropología visual, es un espacio importante que ha servido de ejemplo para otros laboratorios que en los últimos años han surgido en otras universidades, como por ejemplo en el CIESAS (Centro de Investigaciones y Estudios Superiores en Antropología Social), en la ENAH (Escuela Nacional de Antropología e Historia, en el IIA (Instituto de Investigaciones Antropológicas) de la UNAM, instituciones que ya cuentan con centros de producción e investigación en antropología visual. Cada vez hay más estudiantes interesados en aprender lenguaje audiovisual para llevar a cabo sus investigaciones, para comunicar sus resultados, para hacer investigación con metodologías alternativas y narrativas diferentes a las del texto escrito. Hemos hecho varios proyectos en conjunto con profesores y estudiantes en los últimos años, por ejemplo un proyecto muy interesante sobre mercados públicos; ahora nos insertamos en otro proyecto llamado el Observatorio de las periferias, dedicado a realizar producciones audiovisuales sobre regiones periféricas de la ciudad, junto con el Faro de Aragón (Fábrica de artes y oficios Aragón), con la lbero (Universidad Iberoamericana), con el CIESAS; que todos estamos ubicados en alguna periferia. Como esos hay varios proyectos andando, además de que cada estudiante que quiere hacer su proyecto de tesis con una salida audiovisual pues se acerca al laboratorio. Tenemos varios cursos en la licenciatura, también en el posgrado se abrió por primera vez hace unos cuantos años una línea de investigación en antropología visual, entonces la gente que hace el posgrado en ciencias antropológicas lo puede hacer con una especialidad en antropología visual.

CSOnline - Revista Eletrônica de Ciências Sociais, Juiz de Fora, n. 29 (2019) 
Eso hace a la UAM una de las únicas instituciones en México que ofrece antropología visual como una disciplina académica.

¿Cómo comenzó tu trabajo como programador/curador de muestras de cine documental en México, cómo ha sido tu experiencia y que metas te trazaste en ese recorrido?

Todo empezó cuando volví de la maestría en Manchester y quería trabajar para promover y fomentar la antropología visual en México. Me di cuenta de que no había espacios formativos, de exhibición, ni de discusión de antropología visual y me junté con unos colegas de la ENAH que me invitaron a participar en las primeras Jornadas de Antropología Visual que estaban organizando. La experiencia me hizo ver que era una iniciativa que hacía mucha falta en este país, fue mucha gente, había muchos estudiantes de varias universidades que iban a enterarse y ver qué se estaba haciendo. Para las segundas jornadas me integré como coordinador del equipo organizador y crecieron considerablemente, hicimos una muestra de documental etnográfico mexicano, una exposición de fotografía, talleres, mesas redondas, conferencias magistrales. Así se constituyó un grupo de antropólogos egresados de la ENAH que queríamos darle a la antropología visual un lugar más digno. Así hicimos unas siete $u$ ocho jornadas de antropología visual, cada año alrededor del mes de septiembre. Ante la falta de apoyo de las universidades donde estábamos estudiando, particularmente de la ENAH, tuvimos que conseguir becas del FONCA (Fondo Nacional para la Cultura y las Artes), del proyecto de coinversiones culturales para hacer estas actividades y así fue madurando el proyecto. Fuimos trazándonos metas cada vez más ambiciosas, hicimos muestras de cine y retrospectivas de grandes autores y ahí fue cuando decidimos aliarnos con el festival de cine documental DocsDF, que ahora se llama DocsMx.

\section{¿Más o menos de que años hablamos?}

Las primeras jornadas fueron como en 2005 y por ahí de 2011 ó 2012 fue cuando trazamos esa colaboración de DocsDF e hicimos la muestra Cine Entre Culturas. En la primera ocasión fue una muestra pequeña de cinco o seis películas etnográficas internacionales que proyectamos en el CCU (Centro Cultural Universitario, UNAM) y nos fue muy bien, entonces para el siguiente año nos vimos mas ambiciosos e hicimos una retrospectiva de Robert Gardner, un autor emblemático del cine etnográfico y tuvimos la 
suerte de que aceptara nuestra invitación para venir a México, nos dio todos los derechos de su obra sin costo para presentarla y subtitularla, algunas las presentamos en 35 milímetros. Fue un gran salto cualitativo en la difusión del cine etnográfico y la antropología visual en México. A partir de ahí, continuamos la colaboración con DocsDF durante varios años más, bajo el sello Cine entre Culturas programamos retrospectivas de John Marshall por ejemplo, otro gran autor del cine etnográfico norteamericano; Kim Longinotto, una autora británica buenísima que hace cine etnográfico feminista; Jorge Preloran, director argentino poco conocido que creó un estilo propio que llamó cine etnobiográfico; después revisamos el trabajo de dos colectivos de video indígena, hicimos una retrospectiva de Video en las Aldeas, desde la amazonía brasileña, con su fundador Vincent Carelli presente, y otra sobre Ojo de Agua, colectivo oaxaqueño de video indígena y medios comunitarios, cuando cumplían quince años de trabajo.

Así fue como comencé mi incursión en la programación o curaduría de cine, sobre todo de cine documental y etnográfico, con la intención de buscarle ventanas, de que se viera en México lo mejor del cine etnográfico producido en otros países, así como filmes mexicanos poco vistos. Después empecé a involucrarme en otras áreas de la programación, colaborando con el Festival Ambulante; hasta que en 2011 me invitaron abiertamente a trabajar como programador, al mismo tiempo seguía colaborando con DocsMx y terminando mi doctorado en la UAM-I. Todo se fue tejiendo de manera muy orgánica, mi formación académica junto con esta labor de difusión del cine documental y etnográfico, y las ganas de promover la antropología visual. Así fui poco a poco aprendiendo nociones de gestión cultural, cómo buscar recursos, cómo hacer difusión, cómo convocar a los medios, cómo conseguir patrocinadores, ha sido un aprendizaje muy natural, no digo que fácil, pero se fue dando así, sobre la marcha.

¿Cómo entiendes el papel de los festivales documentales en el contexto actual de la circulación de obras en América Latina?

En general tengo una postura crítica y radical ante los festivales, irónicamente porque trabajo en ellos, colaboro con ellos, me encantan y vivo de ellos, sin embargo creo que, en el fondo, los festivales son un mal necesario ante la falta de oferta permanente de iniciativas ciudadanas o del Estado para promover expresiones culturales que no necesariamente son vendibles, pero que valen 
mucho la pena para lograr una diversidad de voces, de disciplinas artísticas y culturales. Frente a la falta de esa oferta permanente en muchas esferas culturales y disciplinas artísticas, han tenido que surgir los festivales, para llenar esos huecos. Hay algo que llamo, con un tono crítico, la festivalización de la cultura, que se refiere al hecho de que, para promover cualquier práctica, cualquier disciplina artística, cualquier expresión cultural, hay que hacerle una fiesta, hay que hacerle un evento de una semana, o de diez días o de tres días, donde se promocione mucho, se invite a la gente, se invite a los medios, hacer mucho ruido para que sea muy visible y sea rentable en el mejor de los casos, pero después de que se acaba el festival, vuelve la sequía, como si hubiera sido un oasis en medio del desierto, y otra vez volvemos a estar en los márgenes, volvemos a tener que luchar para visibilizar, y hay que esperar hasta el próximo año para que vuelva a haber la segunda edición de ese festival y podamos volver a disfrutar algo de cine etnográfico, algo de documental, o de corto experimental, o qué sé yo. En ese sentido digo que son un mal necesario, porque tapan un hueco que debería existir como una oferta permanente en la Cineteca Nacional, en el circuito cultural de exhibición de cine, debería de haber permanentemente ventanas para ver todas estas expresiones audiovisuales, que no llegan normalmente a las salas de cine y entonces tiene que haber festivales de nicho, festivales de cine de terror, festival de cine etnográfico, festival de documental, festival de cortometrajes, festival de cine estudiantil. Amo a los festivales y creo que cumplen una gran labor necesaria para difundir toda esta diversidad de miradas en el mundo audiovisual, pero ojalá que no tuvieran que existir, ojalá que la salida no fuera la festivilización de la cultura, sino que hubiera una oferta constante y permanente.

Yo creo que los festivales cumplen una labor muy importante más allá de la difusión de materiales audiovisuales, que también constituyen puntos de encuentro para la ciudadanía, lugares donde se discute y donde se ponen en juego muchos debates sobre la sociedad, muchos fenómenos y problemáticas del mundo contemporáneo, particularmente en los festivales de cine documental, pues se discuten mucho los temas que tratan las películas. Además, al ser en su mayoría iniciativas ciudadanas, iniciativas que surgen de la sociedad civil, justamente permiten establecer un contrapeso a la cultura institucionalizada, oficial del gobierno.

CSOnline - Revista Eletrônica de Ciências Sociais, Juiz de Fora, n. 29 (2019) 
A veces con ayuda del gobierno, a veces sin ella, pero justo representan puntos de encuentro y apertura para encontrarnos los ciudadanos, para debatir y para pensar en formas posibles de organizar la sociedad de manera distinta. Entonces creo que cumplen además de una función cultural y cinematográfica, una función social y política muy importante.

\section{¿De qué manera las producciones de antropólogos audiovisuales} se insertan en este contexto de festivales de México?

Particularmente la obra de los documentalistas antropológicos o de los antropólogos visuales son producciones que rara vez llega a los grandes festivales de cine. Normalmente tienen estándares de calidad no tan buenos, muchas veces son trabajos de estudiantes de antropología 0 antropólogos profesionales que no tienen un dominio pleno del lenguaje cinematográfico, o la creatividad o la sensibilidad para narrar con imágenes, entonces son filmes que pueden ser muy interesantes desde el punto de vista antropológico pero que a la hora de llegar al gran público, de atrapar y generar empatía, emoción, muchas veces no cumplen su objetivo. Estoy hablando en general, desde lvego que hay honrosas excepciones. Entonces creo que hay dificultad para que estos trabajos encuentren un lugar en festivales, salvo casos muy especiales. Por eso han tenido que surgir festivales especializados en cine etnográfico; en otros países existen festivales muy importantes, en Francia, en Inglaterra, festivales de nicho que están dedicados a ese tipo de cine.

Sin embargo, también es importante mencionar que, a partir del 2005 ó 2006, cuando se fundó el Laboratorio de Etnografía Sensorial en la Universidad de Harvard, se comenzó a hacer un cine etnográfico con un carácter más experimental que se conoce como cine etnográfico sensorial, jugando con las formas, atreviéndose a romper las reglas del lenguaje cinematográfico. Gracias a películas como Leviatán, Sweet Grass, Manakamana, o algunas otras que fueron muy reconocidas, tuvieron muy buena crítica y se ganaron un lugar en los festivales, entonces eso le dio mucha visibilidad al cine etnográfico fuera del circuito de los festivales especializados. Fue un fenómeno muy curioso que también se apagó rápido y ahora otra vez nadie nos voltea a ver a los antropólogos visuales dentro de los festivales de cine documental. Sin embargo, en los festivales donde trabajo, donde 
he colaborado, cuando me invitan a presentar muestras, siempre trato de usar el cine como una especie de caballo de Troya para introducir reflexiones antropológicas.

En publicaciones recientes empleas términos como circuitos alternos, películas marginales y de vanguardia, en referencia a la producción y circulación de obras audiovisuales en los contextos contemporáneos ¿Cómo llegas a formular esos conceptos?

Todo surgió a partir de una invitación a participar en una investigación muy amplia que coordinó Néstor Garcia Canclini, sobre redes y estrategias creativas de los jóvenes para generar alternativas culturales. Había una noción que era central en la investigación y que luego se desechó, que era la idea de los Trendsetters, de los jóvenes que marcan tendencias o que van abriendo brecha para trazar nuevos caminos culturales, emprendimientos 0 iniciativas de gestión cultural, o de empresas o industrias creativas, culturales, artísticas. Esto abarcó muchos campos diferentes, la industria editorial, el campo de la producción musical, etcétera, y lo que yo propuse fue hacer una investigación sobre los festivales de cine que ya empezaban a reproducirse y a tener mucho éxito en México. Todos tenían características similares, estaban encabezados por gente joven, eran festivales que habían surgido desde la sociedad civil, no solo más allá del apoyo del gobierno, sino muchas veces a contracorriente, o a pesar del poco apoyo del gobierno. Todos utilizaban estrategias laborales y de trabajo innovadoras, trabajo por proyecto, freelance, dándole a la gente con que trabajaban la oportunidad de trabajar desde su casa, estrategias muy comunes hoy en día pero que en su momento, hace siete años, todavía eran nuevas formas de organizar el trabajo y organizarse con fines culturales o para llevar a cabo proyectos artísticos. Lo que hice junto con una colega, canadiense, Claudine Cyr, fue hacer una serie de entrevistas, charlas y observación participante en varios festivales de cine, particularmente de cine documental, pero no nos encasillamos exclusivamente en el documental. Así fue como recogimos las experiencias de DocsMx, de Ambulante, de la Casa del Cine, del Festival de la Memoria en Tepoztlán, del Festival Distrital, de algunas iniciativas de distribución de cine alternativo. Justamente nos interesaban estos espacios y estas iniciativas como resistencia a la cultura cinematográfica o audiovisual hegemónica, porque también estaban los grandes festivales como el de Morelia o Guadalajara, 
que son parte de la industria y estrenan películas que después se va a ver en la cartelera comercial. A nosotros nos interesaba conocer esos festivales que apuestan por otras expresiones de la cultura audiovisual, producciones independientes, otros cines 0 cines menores que se ven poco y que tienen pocos espacios de exhibición. A estos festivales que forman circuitos alternativos a la exhibición hegemónica y comercial de cine, los empezamos a ubicar como redes alternativas o circuitos alternos, como subcorrientes o contracorrientes, y con base en esa investigación fue que después desarrollamos un texto llamado Circuitos Alternos, sobre esos flujos de "cines otros".

\section{A partir de ese proyecto, ¿cómo evalúas las producciones de vanguardia en la actualidad en México?}

Esa investigación sobre todo fue acerca de los espacios, de los festivales y de los emprendimientos para difundir el cine, pero también nos llevó a analizar algunas obras emblemáticas de esos circuitos alternos, nos empezamos a enfocar en el análisis del contenido y a ver algunas formas narrativas, formatos, temas, problemáticas recurrentes que abordaban esas "otras producciones". Muchas veces son producciones de vanguardia porque marcan la pauta, a pesar de que se hacen con pocos recursos, escapan a las formulas narrativas convencionales, y entonces proponen nuevas formas de hacer cine. Particularmente hice una curaduría junto con Mara Fortes por encargo del Museo Reina Sofía (Madrid) que se llamó México Inminente, en esa muestra escogimos creo que doce películas mexicanas, tanto de ficción como documentales, y ahí sí que profundizamos más en el contenido, en ver las formas de representación de la realidad, analizamos la problemática a partir de otros medios y luego cómo era vista por el cine. Intentamos tomar autores de vanguardia, 0 autores que van a contracorriente de los formatos convencionales, descubrimos que el cine mexicano está muy valuado, quizás hasta sobrevaluado en los medios y en los festivales extranjeros, pero sin embargo en México es muy poco visto y, aunque presumimos mucho cuando Del Toro gana un Oscar, o cuando Alejandro González Iñárritu gana en los Globos de oro, y todo eso; pero después de todo, al cine mexicano lo seguimos desdeñando y despreciando bastante en nuestro país, es muy poca la gente que paga un boleto en un cine para ver una película mexicana,

CSOnline - Revista Eletrônica de Ciências Sociais, Juiz de Fora, n. 29 (2019) 
al menos de que sea una comedia romántica de Eugenio Derbez o de ese estilo.

Descubrimos que hay una contradicción entre lo cotizado que esta el cine mexicano hacia afuera y lo despreciado que está hacia adentro, ahí hay un cuello de botella, en la difusión, en la distribución del propio cine mexicano, que irónicamente no encuentra a sus espectadores, no encuentra a sus públicos en su propio país, y sin embargo afuera es muy reconocido, premiado y muy bien valorado. Eso un poco en relación con el cine mexicano de vanguardia, que es "farol de la calle, oscuridad de la casa" (dicho popular mexicano).

Uno de los festivales en que realizas curaduría (y apoyas en los debates, etc) es Ambulante, que este año llegó a su 14a edición y que recorre anualmente varios estados de México. ¿Cuál es la importancia de festivales de documentales como Ambulante y su gira en el contexto actual de la circulación de películas en México?

Yo creo que el papel de Ambulante fue crucial para la apertura hacia el cine documental en México. Surgió al mismo tiempo que DocsMx en 2006, en un momento en el que el cine documental era absolutamente marginal y se producía poco y se veía menos. Entonces estos dos festivales fueron pioneros. Bueno, había otras dos experiencias previas como Contra el Silencio Todas las Voces, que era un festival de cine documental independiente hispanoamericano, que se hacía cada dos años, pero yo creo que fueron Ambulante y DocsMx los que realmente abrieron el campo y empezaron a colocar al cine documental en el centro del reflector. La labor de Ambulante es muy importante al llevar esa cultura del cine documental a lugares donde simplemente no existen pantallas de cine para este género, con la filosofía de que si la gente no está yendo al cine a ver documentales por diversas razones -porque no lo exhiben las exhibidoras comerciales, porque está muy lejos, o muy caro- lo que hace Ambulante es llevar el cine hasta donde está la gente, entonces tenemos muchísimas proyecciones al aire libre, en plazas públicas, en escuelas, en museos, y casi todas las funciones son gratuitas. Suena un poco raro decirlo, pero es casi como utilizar al cine documental como pretexto para generar encuentros y debates entre la sociedad civil, para poner temas sobre la mesa con gente que a lo mejor 
nunca hubiera ido al cine a ver una película, pero al llevársela hasta el lugar donde está, se entera de una realidad que desconocía. Además, siempre fomentamos dinámicas participativas, debates con la gente, invitamos a los directores, o hacemos conversatorios con especialistas, entonces el cine documental cumple una función social, la de crear conciencia, descubrir realidades y eventualmente llegar a transformarnos y a transformar la realidad a través del cine documental. Es un festival dedicado al cine documental pero que en realidad es un caballo de Troya para generar dinámicas, encuentros, debates y reflexiones en la gente, por eso creo que son muy importantes los espacios que ha abierto Ambulante y que a lo largo de catorce años ha demostrado que no solamente era pertinente, sino que era necesario, que era urgente y que sigue teniendo todavía muchísimo público, muchísima buena recepción y a pesar de que han habido muchos cambios creo que el espíritu de llevar cultura cinematográfica a regiones donde no la había, sigue siendo muy necesario. Y cómo sigue existiendo la necesidad, ojalá que hayan muchos años más de Ambulante.

Empezaste a responder diciendo que Ambulante movilizó la producción de documentales en México, ¿crees que los festivales DocsMx y Ambulante dieron un impulso para que se hiciera más cine documental en México?

Sí, yo creo que sí, definitivamente, de manera directa y de manera indirecta, o sea, por un lado hay gente que ve un documental que le cambia la vida y entonces sabe que el documental es un lenguaje, un medio posible al alcance de muchos, con las nuevas tecnologías o dispositivos, y que inspirados por documentales que han visto en Ambulante entran y se meten a estudiar cine o se ponen a hacer documentales propios. De manera indirecta, al inspirar o al influenciar a la gente ha crecido la producción, pero también hay muchos estudiantes de cine que ya que saben que existen festivales de cine documental se animan a hacer documentales. Y también de manera directa, tanto Ambulante como DocsMx tienen programas formativos para capacitar gente para hacer documentales, hay talleres para aprender diferentes técnicas, diferentes prácticas dentro del documental: sonido, foto, guion, corrección de color, todo el tiempo hay actividades de formación y de capacitación además del programa permanente que tiene Ambulante, que se llama Ambulante Mas Allá. También 
por muchos años Ambulante tuvo una beca para la postproducción de documentales que se llamaba -dependiendo del patrocinador- la beca Gucci, la beca Cuauhtémoc-Moctezuma, y que representaba un apoyo muy significativo para dos o tres películas cada año, que se volvían producciones también de Ambulante. Entonces sí, de manera directa e indirecta, yo creo que la existencia de festivales fomenta el aumento de la producción de cine documental, inevitablemente, al haber más ventanas para mostrarlos, se producen más.

¿Crees que los festivales de cine en México han roto con hábitos o creado nuevas maneras de ver cine?

Pues no sé si han roto hábitos, porque los hábitos sociales toman muchos años para cambiarse, para romperse, pero sí han abierto nuevas formas, o sí han impulsado estilos distintos de consumo audiovisual, de participación en la cultura audiovisual. Yo creo que estas experiencias que platicaba, de proyecciones al aire libre, de funciones gratuitas, en espacios fuera de las salas de cine, o estas exploraciones de puntos de encuentro entre el documental y otras disciplinas artísticas, que también exploramos mucho, como el teatro documental $\mathrm{o}$ el documental sonoro, el performance; estos intentos para establecer diálogos interdisciplinarios entre el documental y otras disciplinas han formado diferentes hábitos de consumo y recepción del cine documental, nuevos espacios, nuevos lugares y también un público cada vez más exigente, que cada vez más sabe lo que quiere, que quiere ver la última película de Agnès Varda, y entonces sentimos la presión en redes sociales. De alguna manera el público también se ha apropiado del festival y ya exige cosas, que traigamos producciones, entonces yo creo que sí ha fomentado una cultura audiovisual más crítica y un público que se apropia y se adueña más del cine, de las películas y que lo consume de forma más asidua. Yo creo que también se ha formado un nicho de espectadores de cine documental que antes no existía. Ahora ya hay cinéfilos documentales, y eso creo que es una contribución a la formación de públicos, y a otra manera de concebirlo fuera de las pantallas del cine comercial, fuera también del ámbito de los festivales de alfombra roja y del glamour. Más bien un nuevo espacio de encuentro entre las películas y los espectadores que justamente abren la posibilidad de la reflexión, la conciencia, del debate y de la crítica ciudadana. Entonces creo que sí, son nuevas maneras

CSOnline - Revista Eletrônica de Ciências Sociais, Juiz de Fora, n. 29 (2019) 
de relacionarnos con el cine, de vivir del cine, de apropiarnos del cine y también de socializar a través del cine; de establecer vínculos con otras personas, con tus vecinos a través del cine, recomendándoles películas, yendo juntos al cine. Ir al cine debe entenderse como un hecho social, como un fenómeno cultural complejo, creo que es algo que salta mucho a la vista a partir de estos festivales. Creo que sí han cambiado las cosas a partir de la proliferación de festivales, no solo de los de documental sino de muchos otros festivales de géneros artísticos. Entonces, a pesar de que soy crítico con la festivilización de la cultura, también creo que los festivales han generado cambios importantes en la cultura audiovisual, en la manera de relacionarnos con las imágenes y con el cine.

\section{ENTREVISTA EM PORTUGUÊS}

Antonio Zirión Pérez é uma referência na Antropologia Audiovisual mexicana. Professor da Universidade Autônoma Metropolitana, campus Iztapalapa (UAM-I) na Cidade do México, está vinculado ao Laboratorio de Antropología Visual, espaço pioneiro na formação de estudantes nas linguagens audiovisuais no país. Ainda como estudante de etnologia na Escuela Nacional de Antropología y História (ENAH), desenvolveu investigações com o uso de fotos junto a meninos de rua do bairro La soledad, zona marginalizada da região central da CDMX. Como desdobramento da sua monografia de licenciatura, desenvolveu $O$ curtametragem "Chido mi Banda, Chido mi Barrio" (2000), junto com seus companheiros Adrián Arce e Diego Rivera, trio que depois se converteu no coletivo Homovidens. A estratégia de investigaçãoprodução promovida pelo coletivo tinha a finalidade de incluir os jovens na gravação do documentário, ferramenta utilizada pelo cinema participativo. $O$ projeto ganhou nova dimensão a partir de financiamentos privados, com os quais passou a oferecer cursos de vídeo e fotos aos jovens das comunidades da Cidade do México. Todo o processo de ensino-aprendizagem foi registrado e os diferentes materiais geraram o longa-metragem "Voces de la Guerrero" (2004), ganhador do prêmio José Rovirosa de melhor documentário na Universidade Nacional Autônoma do México (UNAM). Após a boa recepção do filme, Zirión saiu do país para fazer seu mestrado em Antropologia Visual no Granada

CSOnline - Revista Eletrônica de Ciências Sociais, Juiz de Fora, n. 29 (2019) 
Centre for Visual Antrhopology, na Universidade de Manchester, Inglaterra. De volta ao México, cursou seu doutorado em Ciências Antropológicas na UAM-I, sob a orientação do antropólogo Néstor García Canclini.

No ano de 2013 o coletivo Homovidens realizou novo projeto com jovens, desta vez detentos na Comunidade de Tratamento Especial para adolescentes San Fernando, localizado na região sul da Cidade do México. O resultado do processo colaborativo foi o documentário "Fuera de Foco" (2013), ganhador do Prêmio de Melhor Documentário no $5^{\circ}$ Festival do Filme Etnográfico de Recife, Brasil. No ano de 2011, após a aposentadoria do professor estadunidense Scott Robinson, fundador do Laboratório de Antropología Visual na UAM-I, Antônio Zirión assumiu definitivamente a responsabilidade de dar continuidade ao ensino de antropologia visual na UAM-I. Desde então, o Laboratório oferece oficinas e ministra disciplinas teóricas e práticas para os cursos de graduação e pós-graduação em antropologia, nas quais os estudantes nacionais e estrangeiros têm a oportunidade de desenvolver o uso da linguagem audiovisual como método de investigação social. Parte da rica produção dos estudantes se encontra disponível na Plataforma Captura de Significados (http://capturadesignificado.org/).

Em paralelo a sua formação acadêmica e aos trabalhos de ensino na UAM-I, Antonio Zirión participa como curador e programador de festivais de documentário, entre eles o DocsDF, DocsMX (https://docsmx.org/) e atualmente na Gira de Documentales Ambulante (www.ambulante.com.mx). Nos últimos anos, 0 antropólogo escreveu artigos onde descreve a importância dos festivais de documentários para a formação de públicos e para a circulação das obras, que dificilmente encontram janelas regulares para serem exibidas. Diante das múltiplas relações que o antropólogo estabelece com o ensino e a pesquisa antropológica, em paralelo ao trabalho na produção e curadoria de festivais audiovisuais, propusemos esta entrevista para compor o Dossiê. Durante a conversa, realizada na tarde do dia 14 de maio de 2019 na UAM-I, o professor nos partilhou algumas de suas reflexões sobre o atual cenário do cinema documental mexicano. 


\section{Você pode nos contar um pouco sobre sua trajetória como antropólogo, sua formação e seus projetos atuais?}

Cursei etnologia na ENAH, ao mesmo tempo em que estudava filosofia na UNAM. Fiz as duas faculdades até que uma greve de nove meses na UNAM me levou naturalmente a me dedicar mais a graduação em etnologia, onde eu já tinha começado a desenvolver minha pesquisa monográfica. Acabei abandonando o carreira de filosofia, mas tudo o que estudei me ajudou muito e acredito que continuo aproveitando em cada trabalho que faço. Esse olhar crítico que te dá à filosofia permanece na minha formação. Fiz minha pesquisa para a monografia de bacharelado sobre um bairro que se chama La Soledad, uma zona com muitos problemas urbanos como: crianças de rua, prostituição, dependentes químicos, muitos cultos e bruxarias urbanas. Lá comecei a utilizar de maneira incipiente, primeiro a câmera fotográfica e depois o vídeo, como instrumentos de investigação. Dessa maneira descobri que existia algo chamado antropologia visual, que eu havia começado a fazer de maneira intuitiva. Terminada essa experiência segui fazendo documentários, com a ajuda de alguns amigos que tinham estudado cinema. Tive a oportunidade de ir à Universidade de Manchester, ao Granada Center, para fazer meu mestrado em antropologia visual e depois voltei para completar minha formação como antropólogo no doutorado em ciências antropológicas na UAM-I. Fiz minha tese junto a pedreiros, trabalhadores da construção, utilizando metodologias audiovisuais. Busquei compreender o desenvolvimento urbano da Cidade do México desde a perspectiva deles. Tive a sorte de ao terminar ser convidado para trabalhar como professor visitante, ministrando alguns cursos. Três anos depois o professor Scott Robinson, que havia fundado o Laboratorio de Antropología Visual, se aposentou e abriram uma vaga justamente com o perfil de antropólogo visual. Tive a sorte de passar no concurso e desde 2011 trabalho aqui no departamento de antropologia, muito próximo ao Laboratorio de Antropología Visual que foi fundado por volta do ano 2000. Pouco a pouco fomos montando um centro de produção de antropologia visual, de vídeo, que naquele momento era vídeo analógico. Conseguimos financiamento para comprar equipamento e começamos a dar aulas de antropologia visual. Ensinamos aos alunos as técnicas básicas de produção, de fotografia e de cinema documental. Desde então se constituiu o laboratório como um espaço único para fazer antropologia visual.

CSOnline - Revista Eletrônica de Ciências Sociais, Juiz de Fora, n. 29 (2019) 
Um espaço pioneiro e visionário no México naquele momento, que vem demonstrando sua pertinência e sua urgência. Porque são poucas as instituições que têm uma linha de pesquisa - o espaço formativo, de pesquisa e de produção em antropologia visual -, e vem servindo de exemplo para outros laboratórios que surgiram em outras universidades nos últimos anos, como por exemplo: no CIESAS (Centro de Invetigacion y Estudos Superiores em Antropología Social) na ENAH; no IIA (Instituto de Investigaciones Antropológicas) na UNAM; instituições que já contam com centros de investigação e produção de antropologia visual. Cada vez existem mais estudantes interessados em aprender a linguagem audiovisual para o desenvolvimento de suas investigações, para comunicar seus resultados, para fazer pesquisas com metodologias alternativas e narrativas diferentes do texto escrito. Fizemos vários projetos em conjunto com professores e estudantes nos últimos anos, entre eles um projeto muito interessante sobre os mercados públicos (na Cidade do México). Agora nos juntamos ao Observatório das Periferias, grupo dedicado a realizar produções audiovisuais sobre regiões periféricas da cidade. Conjuntamente ao Faro de Aragón (Fabrica de artes y Oficios Aragón), com a Ibero (Universidad Iberoamericana), com o CIESAS, estamos todos localizados em zonas periféricas. Existem outros projetos em andamento. A parte, cada estudante do bacharelado que quer fazer seu projeto monográfico com o uso do recurso audiovisual se aproxima do laboratório. Temos várias disciplinas na graduação, também na pós-graduação abrimos, pela primeira vez faz alguns anos, uma área de investigação em antropologia audiovisual. Os alunos da pós-graduação em ciências antropológicas podem fazer uma especialização em antropologia visual. Isso faz da UAM-I uma das instituições que oferece antropologia visual como disciplina acadêmica no México.

Como começou seu trabalho como programador/curador de mostras de cinema documentário no México? Como avalia sua experiência e que metas traçou no percurso?

Tudo começou quando voltei do mestrado em Manchester e queria trabalhar para promover e fomentar a antropologia visual no México. Percebi que não havia espaços de formação, de exibição, nem de discussão de antropologia visual. Alguns colegas da ENAH estavam organizando a Primeira Jornadas de Antropologia Visual e me convidaram para participar. A experiência me fez

CSOnline - Revista Eletrônica de Ciências Sociais, Juiz de Fora, n. 29 (2019) 
ver que era uma iniciativa assim que faltava no país. Contamos com muitos participantes, havia estudantes de muitas universidades que iam se enterrar e assistir ao que estava sendo produzido. Para a segunda jornada me incluí na equipe de organizadores e crescemos consideravelmente. Fizemos uma mostra de documentários etnográficos mexicanos, uma exposição fotográfica, cursos, mesas redondas e conferências magistrais. Assim se constituiu um grupo de antropólogos, vindos da ENAH, que queria dar à antropologia visual um lugar digno. Fizemos por volta de sete ou oito jornadas de antropologia visual, todos os anos por volta de setembro. Diante da falta de apoio (das universidades) onde estudávamos, conseguimos bolsas do FONCA (Fondo Nacional para la Cultura y las Artes), através do projeto de inversões culturais (co-inversiones) para fazermos as atividades e assim o projeto foi amadurecendo. Fomos traçando metas cada vez mais ambiciosas, fazíamos mostras de cinema, retrospectivas de grandes autores. Até decidirmos nos aliar com ao festival de cinema documentário DocDF, que agora se chama DocMx.

\section{Mais ou menos de que ano estamos falando?}

As primeiras jornadas foram por volta de 2005, e ao redor de 2011, 2012 foi que começamos a colaborar com o DocsDF, por meio da mostra Cine entre Culturas. Na primeira edição foi uma mostra pequena, com cinco ou seis filmes internacionais que projetavamos no CCU (Centro Cultural Universitario, UNAM) e a participação foi bem bacana. No ano seguinte fomos mais ambiciosos e propomos uma retrospectiva de Robert Garner, um autor emblemático do cinema etnográfico. Tivemos a sorte de ele aceitar o convite para vir ao México. Ele nos deu os direitos para que pudéssemos exibir e legendar suas obras sem custos, algumas em 35milímetros. Foi um grande salto em termos qualitativos, na difusão do filme etnográfico e da antropologia visual. A partir daí continuamos fazendo essa colaboração durante vários anos com - DocsDF, fizemos várias mostras Cine entre Culturas, fizemos, por exemplo uma retrospectiva John Marshall, outro grande autor do cinema etnográfico estadunidense; Kim Longinotto, uma autora britânica maravilhosa do cinema etnográfico feminista; Jorge Preloran, um argentino pouco conhecido cuja obra esta arquivada no Smithsonian (Instituto Smithsoniano, Estados Unidos); passamos a contar com colaborações internacionais muito importantes. Depois fizemos trabalhos sobre coletivos de vídeos

CSOnline - Revista Eletrônica de Ciências Sociais, Juiz de Fora, n. 29 (2019) 
indígenas, sobre o "Vídeo nas Aldeias" (Brasil); fizemos uma retrospectiva Vicent Carelli que esteve aqui; e sobre Ojo del Agua (México), quando eles cumpriam quinze anos de trabalhos como coletivo de vídeo indígena e de meios comunitários. Fizemos um pouco de tudo, desde retrospectivas de grandes diretores, até curadoria de coletivos de cinema indígenas e comunitários do México, do Brasil e da América Latina.

Assim comecei minha incursão na programação e na curadoria de cinema, sobre tudo de cinema etnográfico, justamente com a intensão de produzir janelas, para que se visse o cinema etnográfico que outros países produziam e que não eram conhecidos no México. Assim como projetos mexicanos que eram também pouco vistos, a ideia era dar maior visibilidade a estes. Depois comecei a me envolver em outras áreas da programação. Sempre colaborei com o Festival Ambulante, o documentário que fiz em 2004, sobre meninos de rua, Voces de la Guerrero, fez parte da primeira Gira de Documetales Ambulante. Na segunda edição me chamaram para proferir uma conferência, na terceira me pediram para ter uma conversa com a diretora vietnamita Trinh T. Minh-há, na quarta me convidaram para escrever um texto. De pouco em pouco fui me envolvendo mais com Ambulante e na sexta Gira me chamaram abertamente para trabalhar como programador. Ao mesmo tempo seguia colaborando com 0 DocDF e terminando meu doutorado na UAM-I. Tudo foi se dando de maneira muito orgânica, minha formação acadêmica junto com o trabalho de difusão do cinema documentário e etnográfico, a vontade de promover a antropologia visual. Dessa maneira fui aos poucos aprendendo noções de gestão cultural, de como buscar recursos, como fazer difusão, como contactar os meios, como trazer os convidados, o que oferecer para eles, como conseguir patrocinadores, foi um aprendizado muito natural e orgânico. Não foi fácil, mas digamos que tudo foi se dando ao mesmo tempo.

\section{Como você entende o papel dos festivais de documentários no contexto atual de circulação das obras na América Latina?}

Em geral tenho uma postura um pouco crítica e radical diante dos festivais. Ironicamente porque trabalho neles, colaboro com eles, me encantam e vivo deles. Contudo, acredito que pode soar um pouco forte, mas vejo eles como um mal necessário. Diante

CSOnline - Revista Eletrônica de Ciências Sociais, Juiz de Fora, n. 29 (2019) 
da falta de iniciativas permanentes para uma oferta, da sociedade civil ou do Estado, em promover expressões culturais que não necessariamente são vendáveis. Mas que ainda assim, valem a pena para alcançar uma diversidade de vozes, de disciplinas artísticas e culturais. Diante da falta de ofertas permanentes de esferas culturais e disciplinas artísticas surgem os festivais, para ocupar esses vazios. Há um termo que utilizo em tom crítico, a festilização da cultura, que se refere ao fato que para promover qualquer prática, qualquer disciplina artística, qualquer expressão cultural, é preciso fazer uma festa. Temos que fazer um evento de uma semana, de dez dias ou três dias, se seja muito divulgado. É preciso trazer convidados, chama à imprensa, fazer muito ruído para que chame a atenção e seja rentável, no melhor dos casos. Depois que acaba o festival, tudo volta à seca, como se tivesse sido um oásis no meio do deserto. Outra vez voltamos a estar à margem, voltamos a lutar por visibilidade, precisamos esperar até o próximo ano para fazer a segunda edição desse festival e podermos voltar a disfrutar de algum cinema etnográfico, algum documentário, ou de curtas experimentais, entre outros. Nesse sentido digo que são um mal necessário, porque ocupam um vazio que deveria ser ocupado por uma oferta permanente na Cineteca Nacional, nos circuitos culturais de exibição, nos cinemas. Deveriam existir janelas permanentes para todas as expressões audiovisuais, que normalmente não chegam às salas de cinema. Então é preciso realizar festivais de nicho, festivais de cinemas de terror, festival de filme etnográfico, festivais de documentários, festivais de curta-metragem, de Cinema Universitário. Amo os festivais e acredito que cumprem um grande trabalho necessário para difundir toda a diversidade de olhares do mundo audiovisual, mas seria incrível se não fossem a festilização da cultura, e sim existisse uma oferta constante e permanente.

Eu acredito que os festivais cumprem um trabalho muito importante, para além da difusão de materiais audiovisuais, pois são também pontos de encontro para os cidadãos. Lugares onde se discute e onde ocorrem muitos debates sobre a sociedade, muitos fenômenos e problematizações do mundo contemporâneo, particularmente os festivais de cinema documentário onde se discute muitos temas tratados nos filmes. Além de a maior parte ser iniciativas populares, que surge da sociedade civil, justamente permite estabelecer um contraponto à cultura institucionalizada, 
oficial do governo. Por vezes com ajuda do governo, as vezes sem ela, mas justamente representam um ponto de encontro $e$ abertura para o encontro da população, para debater e pensar formais possíveis de organizar a sociedade de maneira distinta. Então creio que cumprem, além de uma função cultural e cinematográfica, uma função social e política muito importante.

\section{De que maneira as produções de antropólogos audiovisuais se inserem nesses contextos de festivais no México?}

Particularmente a obra de antropólogos documentaristas ou de antropólogos visuais são produções que raramente chega aos grandes festivais. Normalmente a qualidade técnica não é tão boa, em muitos casos são trabalhos de estudantes de antropologia ou antropólogos profissionais que não dominam plenamente a linguagem audiovisual, ou da criatividade, ou da sensibilidade de narrar com imagens. Acabam sendo imagens que podem ser muito interessantes desde o ponto de vista antropológico, mas que no momento de chegar ao grande público, de fisgar e promover empatia, emoção, em muitos casos não cumpre esse objetivo. Estou falando no geral, existem honrosas exceções, então acredito que existe dificuldade para que esses trabalhos encontrem um lugar nos festivais, salvo casos muito especiais. Por isso surgiram os festivais de filme etnográfico, no México existem alguns. Iniciativas como essa que falei, as Jornadas de Antropología Visual, a Mostra Cinematográfica Cine Entre Culturas, em outros país existem festivais muito importantes, na França, na Inglaterra, mas são festivais de nicho que estão dedicados a esse tipo de filmes. Contudo, é importante mencionar que a partir de 2005, 2006, ou talvez um pouco depois, quando se fundou 0 Laboratório de Antropologia Sensorial, na Universidade de Harvard, começou a se produzir um cinema etnográfico com um caráter experimental, jogando com as formas, se atrevendo a romper as regras da linguagem cinematográfica, conhecido como filme etnográfico sensorial. Graças a filmes como Leviatán, como Sweet Grass, Manacamana, ou algumas outras que ganharam lugar nos festivais, foram reconhecidas, tiveram excelentes críticas e acabaram dando visibilidade aos filmes etnográficos fora do circuito dos festivais especializados. Foi um fenômeno muito curioso que acabou rápido, agora ninguém se volta para ver os antropólogos visuais nos festivais de cinema documentário. Contudo, nos festivais aonde trabalho, aonde venho colaborando, 
quando me convidam para organizar uma mostra sempre uso o cinema como uma espécie de "Cavalo de Troia" para incluir conteúdos e reflexões antropológicas. Para que coexistam filmes etnográficos e cinema documentário, mas ao mesmo tempo cada um tem seus nichos de especialidades separados.

Nos seus últimos artigos você emprega termos como circuitos alternos, películas marginales e vanguardias, referindo-se a produção e circulação de obras audiovisuais nos contextos contemporâneos. Como você formula esses conceitos?

Tudo surgiu a partir do convite para participar de uma pesquisa abrangente coordenada por Néstor Garcia Canclini, acerca das redes e estratégias criativas dos jovens para gerar alternativas culturais. Havia uma noção central na investigação e que logo de descartou, a ideia dos trendsetters, dos jovens que marcam tendência ou que vão abrindo brechas para trazer novos caminhos culturais, empreendimento ou iniciativas de gestão cultural, ou de empresas da indústria criativa, culturais, artísticas. Dessa forma abarcou muitos campos diferentes: a indústria editorial, o campo da produção musical, etc. e o que propus foi fazer uma pesquisa sobre os festivais de cinema, que começavam a reproduzir e ter muito êxito no México. Todos tinham características similares, eram encabeçados por pessoas jovens, eram festivais que surgiram da sociedade civil, não apenas para além do apoio do governo, se não muitas vezes contra a corrente, ou apesar do pouco apoio do governo. Todos utilizavam estratégias de trabalho inovadoras, trabalho por projeto, freelance, dando às pessoas a oportunidade de trabalharem desde casa. Estratégias muito comuns hoje em dia, mas naquele momento, há sete anos atrás, eram maneiras novas de organizar o trabalho, de organir-se para fins culturais e para fazer projetos artísticos. O que fiz junto com uma colega canadense, Claudine Cyr, foi fazer uma série de entrevistas, conversas e observação participante em vários festivais de cinema, particularmente de cinema documentário, mas não limitamos apenas aos de documentários. Desta forma percorremos as experiências do DocsMx, do Ambulante, da Casa del Cine, do Festival de la Memoria em Tepoztlán, do Festival Distrital, de algumas iniciativas de distribuição de cinema alternativo. Justamente nos interessavam esses espaços e estas iniciativas como resistência à cultura cinematográfica ou audiovisual hegemônica, porque 
também estavam os grandes festivais de Morelia ou de Guadalajara, que são parte da indústria e estreiam filmes que depois serão vistos no circuito comercial. Nos interessava conhecer estes festivais que apostam em outras expressões da cultura audiovisual, produções independentes, outros cinemas ou filmes menores que são pouco vistos e que têm pouco espaço para exibição. Estes festivais que formam circuitos alternativos à exibição hegemônica e comercial de cinema, começamos a classificar como redes alternativas ou circuitos alternos, como subcorrentes ou contracorrentes, e com base nessa investigação foi que depois desenvolvemos um texto chamado Circuitos Alternos, sobre a circulação desses "outros cinemas".

\section{A partir desse projeto, como você avalia a produção de vanguarda atualmente no México?}

Essa investigação foi sobre tudo sobre os espaços dos festivais e dos empreendimentos para difundir filmes, mas também nos levou a analisar algumas outras emblemáticas desses circuitos alternos. Começamos a focar na análise do conteúdo e a ver algumas formas narrativas, formatos, temas, problemáticas recorrentes que eram abordadas nessas "outras produções". Muitas vezes são produções de vanguarda porque marcam a pauta. Apesar de serem realizadas com poucos recursos, escapam as formas narrativas convencionais e/ou propõe novas formas de se fazer cinema. Particularmente, fiz uma curadoria junto com Mara Fortes a pedido do Museu Reina Sofia (Madrid) que se chamou México Inminente. Nessa mostra escolhemos doze filmes mexicanos, tanto de ficção como de documentário, e ali sim aprofundamos mais nos conteúdos, em observar as formas de representação da realidade. Analisamos a problemática a partir de outros meios e logo como era entendida pelo cinema. Tentamos pegar alguns autores de vanguardas, ou autores que são contracorrente dos formados convencionais. Descobrimos que o cinema mexicano é valorizado, talvez até supervalorizado nos meios e nos festivais estrangeiros, contudo é pouco visto no México. Por mais que nos presumamos muito quando Del Toro ganha um Oscar, ou quando Alejandro González Iñárritu ganha o Globo de Ouro. Mas o cinema mexicano continua sendo desdenhado e desprezado no nosso país. São poucas as pessoas que pagam entradas de cinema para ver um filme mexicano, ao menos que seja uma comédia romântica do Eugenio Derbez ou desse estilo. 
Descobrimos que há uma contradição entre a valorização do cinema mexicano no exterior e o desprezado internamente. Há um gargalo na difusão, na distribuição do próprio cinema mexicano, que ironicamente não encontra aos seus espectadores. Não encontra seus públicos no próprio país e no exterior é reconhecido, premiado e muito valorizado. Isso um pouco em relação ao cinema mexicano de vanguarda, que é o "farol de la calle, oscuridad de la casa" (dito popular mexicano: "farol nas ruas, escuridão da casa")

Um dos festivais que você faz curadoria (e apoia nos debates, etc.) é o Ambulante, que este ano chegou a sua $14^{a}$ edição e recorre anualmente vários Estados do México. Qual é a importância de festivais de documentários como o Ambulante e sua Gira (itinerância) no contexto contemporâneo de circulação de filmes no México?

Eu acredito que o papel do Ambulante foi crucial para a abertura para o cinema documentário no México. Surgiu ao mesmo tempo que o DocsMx, em 2006, num momento onde o cinema documentário era absolutamente marginal, se produzia pouco e se via ainda menos. Então esses dois festivais foram pioneiros. Houve duas experiências anteriores, como o Contra el Silencio Todas las Voces (Contra o silêncio todas as vozes), que era um festival de filmes documentário independentes hispanoamericano, realizado a cada dois anos, mas eu acredito que foram o Ambulante e o DocsMx os que realmente abriram 0 campo e começaram a colocar o cinema documentário no centro dos refletores. O trabalho de Ambulantes é muito importante por levar a cultura dos filmes documentários a lugares onde simplesmente não existe telas de cinema para esse gênero. Tem a filosofia de que se as pessoas não estão indo ao cinema ver documentários é por diversas razões: porque não são exibidos pelas exibidoras comerciais, porque estão muito longe, ou muito caro. O que o Ambulante faz é levar o cinema até onde estão as pessoas. Realiza muitas exibições ao ar livre, nas praças públicas, nas escolas, nos museus e quase todas as projeções são gratuitas. Soa um pouco estranho dizer, mas é quase como utilizar os documentários como pretexto para gerar encontros e debates entre a sociedade civil. Para por temas sobre a mesa com pessoas que muitas vezes nunca iriam ao cinema ver um filme, mas ao encontrarem a possibilidade de assisti-los nos seus locais, 
iteram-se de uma realidade que desconheciam. Além disso, sempre fomentamos dinâmicas participativas, debates com as pessoas, convidamos aos diretores e fazemos debates com especialistas. Dessa maneira o cinema documental cumpre sua função social: a de criar consciência, descobrir realidades, eventualmente chegar a nos transformar e a transformar a realidade por meio do documentário. É um festival dedicado aos documentários, mas na realidade é um "Cavalo de Tróia", para gerar dinâmicas, encontros, debates e reflexões nas pessoas. Por isso acredito que são muito importantes os espaços que foram abertos pelo Ambulante e que ao longo de quatorze anos vêm demonstrando que não era apenas pertinente e sim necessário. Que era urgente e que segue tendo um grande público, muito boa recepção. Apesar de terem ocorrido muitas mudanças acredito que o espírito de levar a cultura cinematográfica a regiões onde não havia, segue sendo muito necessário. E como segue existindo a necessidade tomara que tenham muitos anos mais de Ambulante.

Você começou comentando que o Ambulante movimentou a produção de documentários no México. Você acredita que os festivais DocsDF e Ambulante deram um impulso para que se realizasse mais filmes documentários no México?

Sim, eu acredito que sim, definitivamente, de maneira direta e de maneira indireta. Ou seja, por um lado existem pessoas que assistem a um documentário que modifica sua vida e então passam a saber que o documentário é uma linguagem, um meio possível ao alcance de muitos com as novas tecnologias ou dispositivos. E que inspirados em documentários que viram no Ambulante passam a estudar ou a fazer documentários próprios. De maneira indireta ao inspirar e influenciar pessoas. Tem crescido a produção, também porque muitos estudantes de cinema, sabendo da existência de festivais voltados para documentários, se animam a produzir filmes do gênero. E também de maneira direta, tanto Ambulante como DocMx, têm programas formativos de capacitação para pessoas realizarem documentários, com aulas onde se aprendem diferentes técnicas: som, correção de cor, entre outros, ou seja, sempre existem atividades de formação e de capacitação. Além do programa permanente do Ambulante, chamado Ambulante Mas Allá. Por muitos anos o Ambulante tinha uma bolsa para pós-produção de 
documentários que variava dependendo do patrocinador Gucci, Cuauhtémoc Moctezuma - e que era um apoio generoso para dois ou três filmes a cada ano, que se tornavam produções apoiadas pelo Ambulante. Desta forma, de maneira direta e indireta, eu acredito que a existência de festivais inevitavelmente fomenta o aumento da produção de documentários. Ao abrir janelas para se exibir, se produz mais.

\section{Você acredita que os festivais de cinema no México modificaram hábitos ou criaram novas maneiras de se assistir filmes?}

Não sei se modificaram hábitos, porque os hábitos sociais dependem de muitos anos para modificarem, para romper. Mas acredito sim que existem novas formas e que têm impulsionado estilos distintos de consumo audiovisual. Eu acredito que essa experiência que contava das projeções ao ar livre, as funções grátis, em espaços foras das salas de cinema, ou essas atividades exploratórias para $\circ$ ponto de convergência entre os documentários e outras disciplinas artísticas como: o teatro documental ou o documentário sonoro, as performances; as tentativas de estabelecer diálogos interdisciplinares entre o documentário e outras disciplinas, têm formado diferentes hábitos de consumo e recepção para os documentários. São novos espaços, novos lugares e também um público cada vez mais exigente, que cada vez mais sabem o que querem e pedem: querem assistir o último filme de Agnès Varda. Sentimos a pressão das redes sociais. De alguma maneira o público também se apropriou dos festivais. Faz exigências para trazermos produções. Acredito que se fomentou uma cultura audiovisual mais crítica, um público que se apropria e se apodera do cinema, dos filmes e que o consome de maneira mais assídua. Eu acredito que se formou um nicho de espectadores de cinema documentário que não existia antes. Agora existem cinéfilos de documentários, e isso acredito que é uma contribuição da formação de públicos, e as outras maneiras de concebê-los fora das telas do cinema comercial, fora também dos festivais do "tapete vermelho" e do glamour. Melhor dizendo, um espaço para o encontro entre os filmes e os espectadores onde justamente se abre a possibilidade de reflexões, de consciência, do debate e da crítica social. Por isso acredito que sim existam novas maneiras de se relacionar com o cinema, de viver o cinema, de se apropriar do filme e também de sociabilizar, ou sociabilidades por meio do cinema. De

CSOnline - Revista Eletrônica de Ciências Sociais, Juiz de Fora, n. 29 (2019) 
estabelecer vínculos com outras pessoas, com seus vizinhos através do cinema, recomendando filmes, indo juntos ao cinema. Ir ao cinema como um ato social, como um fenômeno complexo. Acredito que é algo que salta aos olhos nesses festivais. Creio que as coisas vêm mudando a partir da proliferação de festivais, não apenas de documentários, mas também de muitos outros festivais de gêneros artísticos. Então, apesar de ser muito crítico com a festilização da cultura, também acredito que os festivais vêm gerando mudanças importantes na cultura audiovisual, na maneira de relacionarmos as imagens com o cinema. 